\title{
Evaluation of Phosphate Analysis and the Brongers Method of Detecting Decomposed Wood, Human Tissue and Organic Goods in a Bell Beaker Grave at Těšetice-Kyjovice, Czech Republic
}

\author{
Michal Hlavica ${ }^{a}$, Jan Petřík ${ }^{b}$, Lubomír Prokešc ${ }^{c}$ Klára Šabatováa \\ anstitute of Archaeology and Muzeology, Faculty of Arts, Masaryk University, Arne Nováka 1, Brno, Czech Republic \\ ${ }^{b}$ Institute of Geology, Faculty of Natural Sciences, Masaryk University, Kotlářská 2, Brno, Czech Republic \\ 'Institute of Chemistry, Faculty of Natural Sciences, Masaryk University, Kamenice 5, Brno, Czech Republic
}

\section{ARTICLE INFO}

\section{Article history:}

Received: 25 November 2011

Accepted: 20 December 2011

\section{Keywords:}

Bell Beaker grave

funerary rite

grave construction

geochemical soil analyses

GIS

spatial analysis

\section{Introduction}

The research at Těšetice-Kyjovice in south-west Moravia (Figure 1) is currently focused on the methodology and the systematic recording of the archaeological context. The excavation of Bell Beaker grave H27 was carried out at the "Sutny II" site in 2010-2011. The grave is comprised of a chamber, surrounded by a trough, containing a well-equipped skeleton (Kuča et al. in print). The skeleton was identified as male, and was found oriented with its head to the north, lying on its side, on the bottom of the grave pit (Figure 2). During the analysis of the chamber certain experimental methods were used including a geochemical phosphate analysis to identify soft tissue decomposition, and the J. A. Brongers method for depicting organic structures.

"Corresponding author. E-mail: sabatova@phil.muni.cz
A large body of research supports the benefits of the use of a phosphate analysis in an analysis of the archaeological contexts (Stoye 1950; Piggot 1956; Barker et al. 1975; Duma 1972; Núñez 1975; Cavanagh et al. 1988; Turek, Majer 1999; Crowther 2002; Holliday, Gartner 2007; Ernée, Majer 2009; Petrrík et al. 2012). The aim of this paper is to analyse phosphate distribution and decomposed wooden structure modelling in the grave pit with an interpretation of the results from the standpoint of the Bell Beaker burial rite.

The use of Brongers method in the analysis of the grave was partially associated with the fact that several dark features, possible signs of wooden grave structures, were detected in the subsoil of the grave pit during the spring research, while in the summer months these features were no longer identifiable in the subsoil. The authors are not aware of any practical use of this method in archaeology and this paper is the first appraisal of this method to identify the construction of grave chambers. 


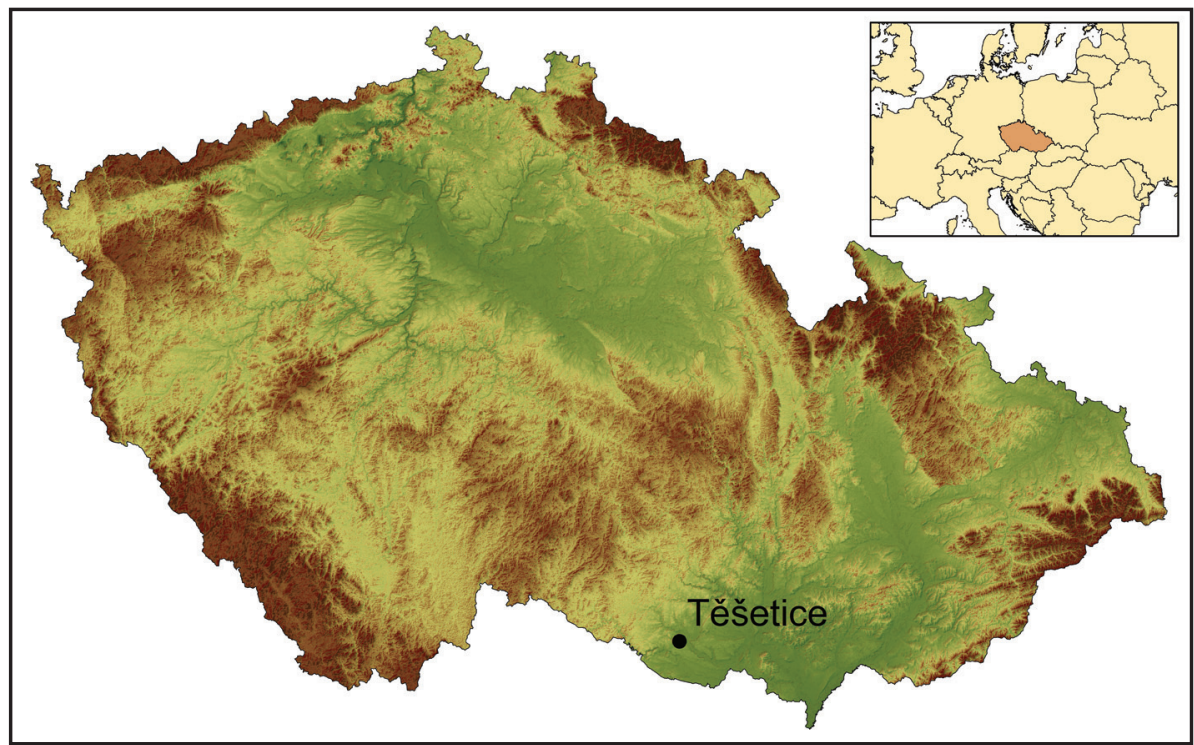

Figure 1. Site location on the map of the Czech Republic

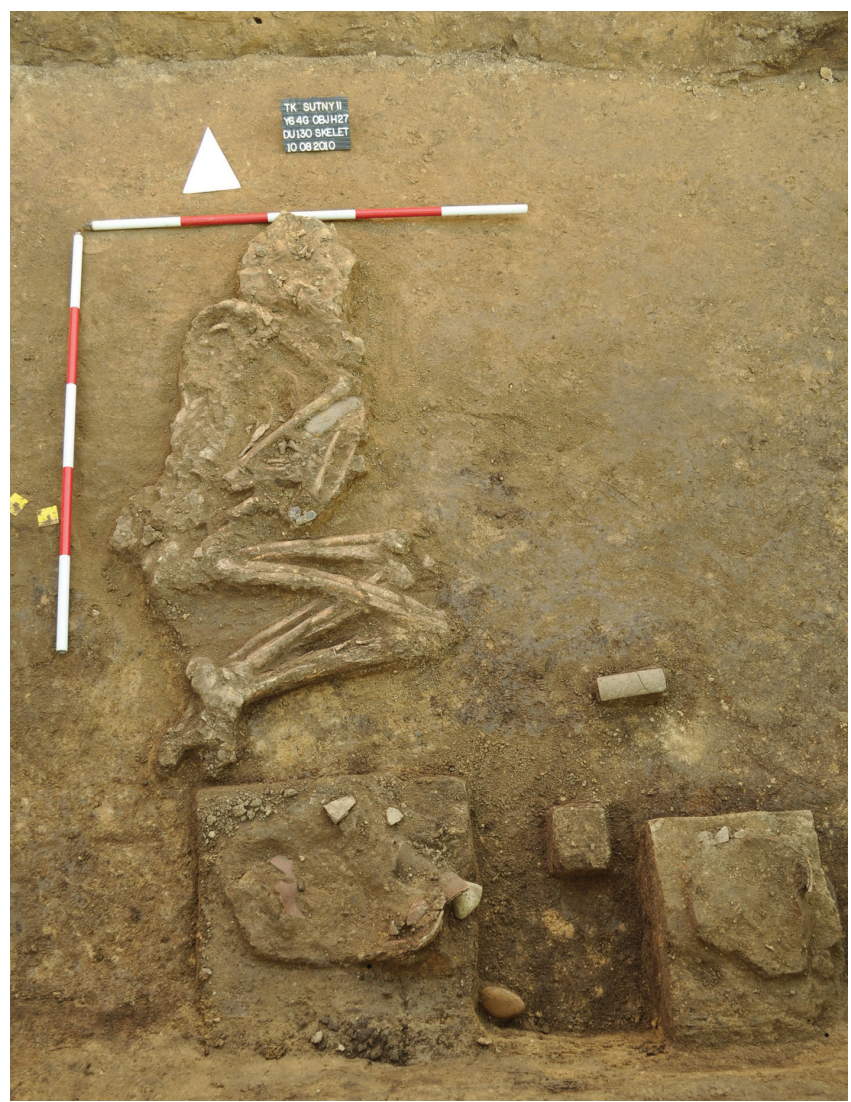

Figure 2. Skeleton uncovered in the grave $\mathrm{H} 27$.

The aim of this paper was therefore to answer the following research questions: could any source of anthropogenic phosphates be recognized in the grave? Is there a spatial relationship between phosphates, the skeleton or other features? Can we effectively recognize new features by employing Brongers method? Can the phosphate analysis and Brongers method be combined in order to define a logical structure which improves funerary rite research?

\section{Methods}

During the archaeological excavation of the grave chamber the context was recorded in levels, from the surface. The context was recorded at $20 \mathrm{~cm}$ (in the top soil) and $40 \mathrm{~cm}$ (an outline of the grave pit at the subsoil level), $55 \mathrm{~cm}$ and $70 \mathrm{~cm}$ depth (the grave within the subsoil) and from $70 \mathrm{~cm}$ to the bottom of the chamber at $140 \mathrm{~cm}$ after $10 \mathrm{~cm}$ levels (extremely precise recording). Samples for phosphate analysis were taken from seven recording levels (Figure 3). Brongers method was tested at the recording levels $40 \mathrm{~cm}$, $110 \mathrm{~cm}$ and $140 \mathrm{~cm}$.

Samples for geochemical analysis were taken in a $15 \mathrm{~cm}$ regular "grid". The phosphates were treated using the A. Majer method (1984) and extracted in hydrochloric acid. Phosphates were subsequently identified through photometry using the Murphy and Riley method (1962).

The authors concluded empirically that the method needed to be adapted to the geochemical conditions on the site. A comparison of the results from site to site could consequently be problematic (see Holiday and Gartner 2007, for references and comments on the single methods of phosphate soil analysis).

The subsoil of the site is formed by alkaline loess with overlying brown soil. Soil $\mathrm{pH}$ determined from soil infusion to deionized water is $7-8$ and the soil texture of the brown soil and grave infill is described as silty loam.

Burial taphonomy and the basic physical characteristics of the skeleton have been described in a recent paper (Petrrík et al. 2012).

In an attempt to visualize phosphates directly in the field, aerosols of phosphate analysis reagents were sprayed directly on the cleaned surface using Eidt method (1973).

The decomposed wood remains were identified using the solutions of nitric acid $\left(\mathrm{HNO}_{3}\right)$ and potassium rhodanide (KSCN) as described by Brongers (Brongers 1962-1963; Rotländer 1970).

These authors demonstrated the validity of the results despite the fact that the mechanism of this method is not 
precisely known. The method apparently relates to iron accumulation in the soil during the wood decomposition. A practical application was realized by direct aerosol spreading on to the soil surface.

A visible picture was outlined in the field and surveyed by a total station. Interpolation of recorded data was carried out in the GIS environment using the Natural Neighbour method (Sibson 1981). ESRI Arc GIS 10 software was used for interpolation and a visual display of the data.

\section{Theories and reasoning}

It was theorized that if the location proved appropriate for the chosen geochemical methods of analysis, then phosphate soil analysis would determine whether soft tissue decomposition occurred in the vicinity of the skeleton. If the grave pit was to contain other phosphate sources, such as organic grave inclusions, they would also be identified and their location determined.

The macroscopic identification of the decomposed wooden features is often impossible. Brongers method was selected for use in order to identify possible remnants of wooden structures within the grave chamber.

\section{Results}

\subsection{Phosphate Analysis}

A comparison of phosphate values obtained at various levels reveals a pronounced variance at $20 \mathrm{~cm}$ below the surface (Figure 3), within the top soil, and is certain to relate to plant nutrition, fertilization, the presence of archaeological objects, etc. The median values slowly increase from $40 \mathrm{~cm}$ to $100 \mathrm{~cm}$ below the surface. A significantly higher phosphate concentration was found at $130 \mathrm{~cm}$ below the surface, where a skeleton had been situated.

The equivalence of the phosphate concentrations at different layers was tested with the Kruskal-Wallis rank test, related to a one-way analysis of variance. The results of the test indicate an extremely low probability of equivalence of the mean phosphate concentrations of all the recording levels $(\mathrm{p}<2.2 \mathrm{e}-16$ for $\alpha=0.05)$. Using a multiple comparison procedure (for $\alpha=0.05$ ), the recording levels 130 and 140 were found to be different from the phosphate concentration at other levels. In recording level 130, related to the buried body, phosphate was accumulated. In contrast, recording level 140 contained the lowest amount of phosphate.

\section{1 .1 Recording level $110 \mathrm{~cm}$}

Further excavation determined that this level lies several centimetres above the skeleton, indicating that the phosphates at this level were unlikely to originate from human tissues. The distribution of phosphate concentrations is depicted in the kernel density estimation, as kernel density estimation diagrams effectively illustrate value distribution, which does not indicate any signs of multimodality (Figure 4).

\section{1 .2 Recording level $130 \mathrm{~cm}$}

This level lies directly under the skeleton. The kernel density estimation plot suggests bimodality in the phosphate value distribution when compared with the Gaussian distribution function (Figure 5). This could be caused by the presence of anthropogenic phosphates. The data interpolation in the area reveals a marked anomaly corresponding with the area of the skeleton (with a slight shift to the right) as well as high distributions in the area of the legs and at the east border of the distribution map (Figure 6). The attempt to identify phosphates directly in the field (between recording level 130 and $140 \mathrm{~cm}$ ) yielded a somewhat different result. The blue stain indicating phosphates corresponded with the location of the skeleton including the right shift of the anomaly as at recording level $130 \mathrm{~cm}$, just under the skeleton (Figure 7).

\section{1 .3 Recording level $140 \mathrm{~cm}$}

The kernel density estimation plot of the frequency function suggests an irregular distribution of values in this data set (Figure 8). Despite the fact that there is no clear bimodality, the value distribution is extremely similar to the $130 \mathrm{~cm}$ level. High phosphate values are concentrated in the skeleton
Figure 3. Bar diagram of the phosphate concentrations at various recording levels.

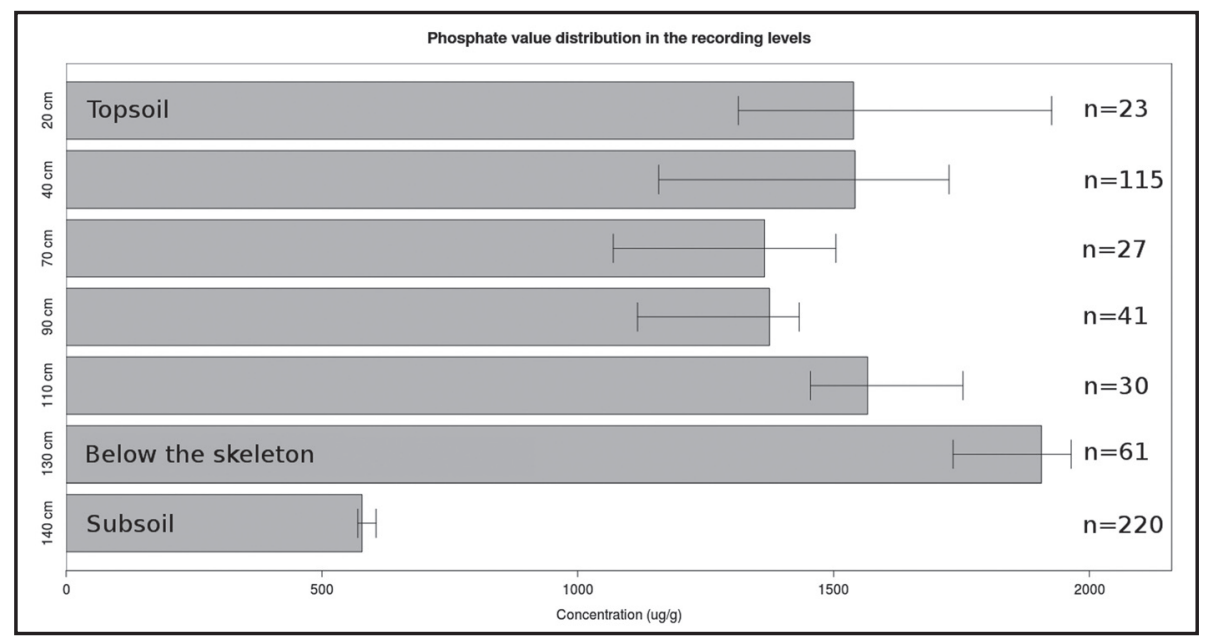



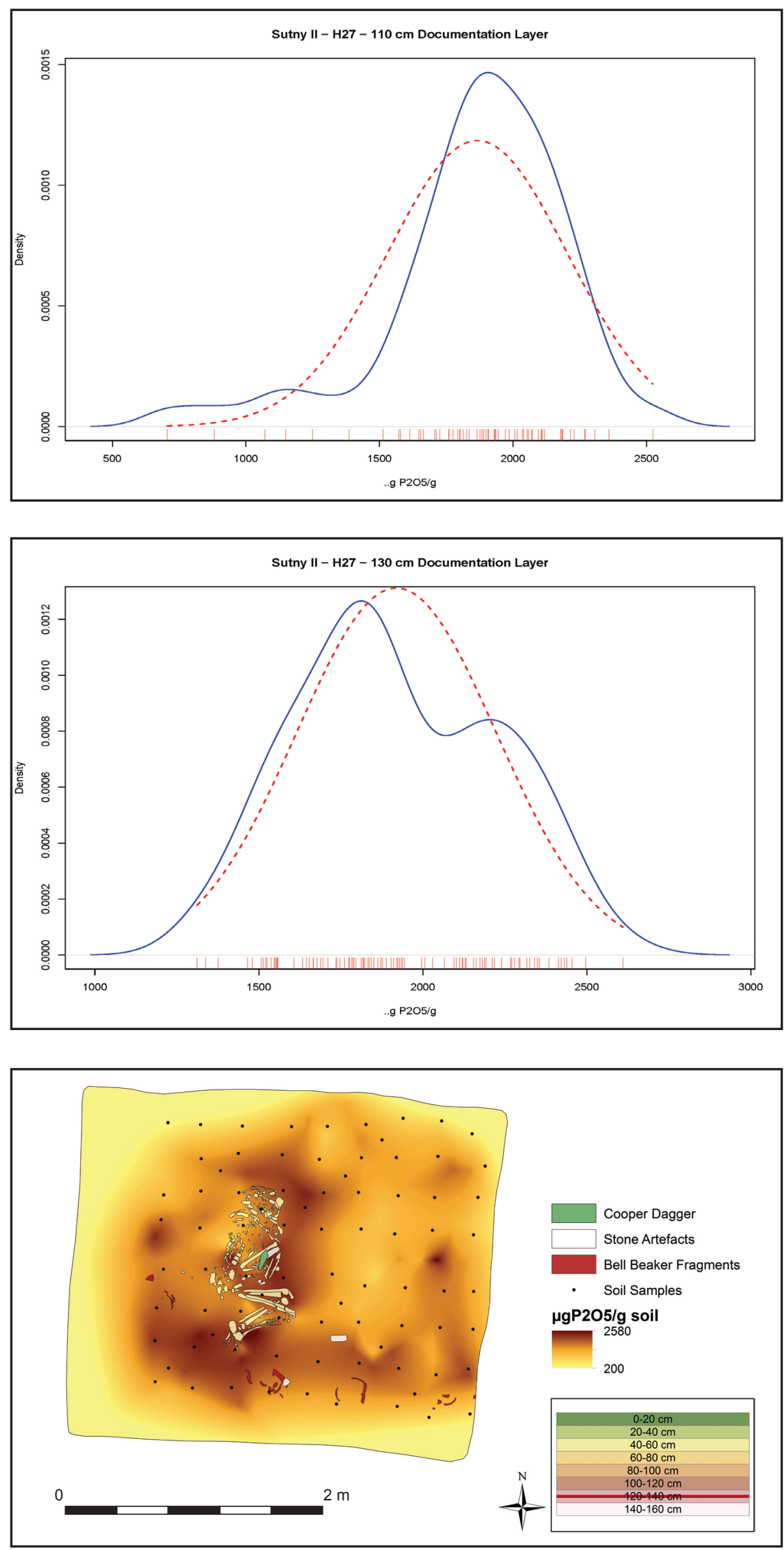

Figure 4. Kernel density estimation soil phosphates values, level $110 \mathrm{~cm}$. The red line represents the normalized Gaussian curve.

Figure 5. Kernel density estimation of soil phosphates values, level $130 \mathrm{~cm}$. The red line represents the normalized Gaussian curve.

Figure 6. Soil phosphates values interpolated by the Natural Neighbour method, level 130 $\mathrm{cm}$ below the surface. 
Figure 7. Results of field visualization of soil phosphates.

Figure 8. Kernel density estimation of soil phosphates values, level $140 \mathrm{~cm}$. The red line represents the normalized Gaussian curve.

Figure 9. Soil phosphates values interpolated by the Natural Neighbour method, level 140 $\mathrm{cm}$ below the surface.
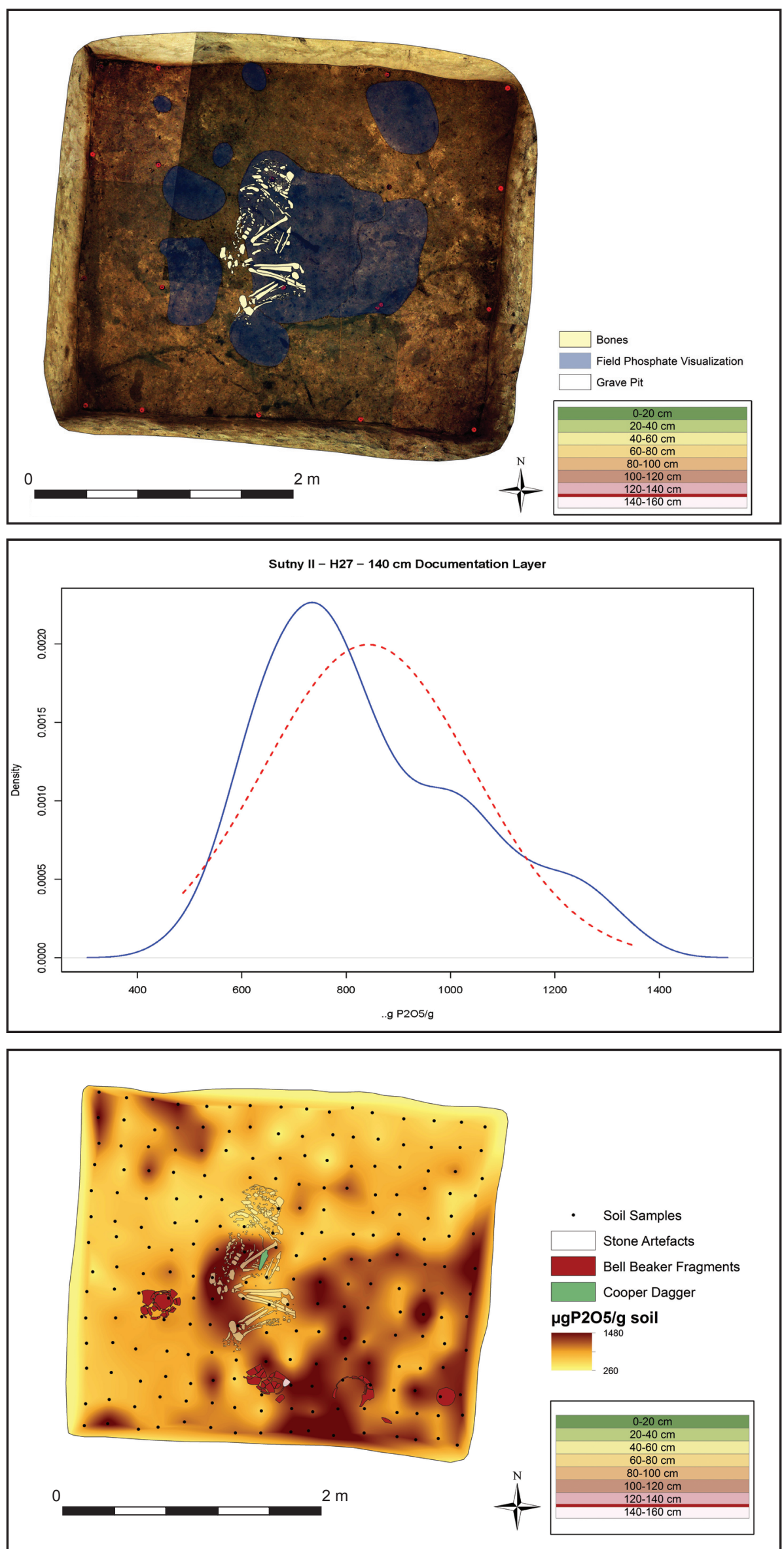
area (just as at the $130 \mathrm{~cm}$ level) as well as in the southeast part of the grave chamber (Figure 9).

\subsection{Brongers Method}

Rhodanide was applied experimentally at the top layers on the profile as well as on part of the grave pit at the subsoil level, in order to determine whether the remnants of decomposed wood could be identified. A marked reaction was observed in the northern part of the grave (Figure 10) but not in the southern part. As shown by a subsequent investigation, the southwest corner of the grave fill was contaminated by inclusions of an earlier LBK construction pit which was disturbed by the digging of this grave. A subsequent trial was conducted after the removal of the entire top layer of soil down to the loess (recording level $40 \mathrm{~cm}$ ), at recording level
$110 \mathrm{~cm}$ over the skeleton, and at the bottom of the grave pit after the skeleton was removed (recording level $140 \mathrm{~cm}$ ).

\section{2 .1 Recording level $40 \mathrm{~cm}$}

The Brongers method was applied to the entire area of the grave chamber after the grave pit was cleaned up to the subsoil level. This yielded surprising results. The entire grave pit was surrounded by a red-coloured belt. A cross bar dividing the grave chamber and running in the northsouth direction and perhaps the beginning of another cross bar stemming from the northern side of the grave chamber were also observed (Figure 11). These features may be remnants of the ceiling of the grave chamber. In order to clarify the entire picture, outlines were marked into the soil and subsequently recorded by a total station. A terrain sketch
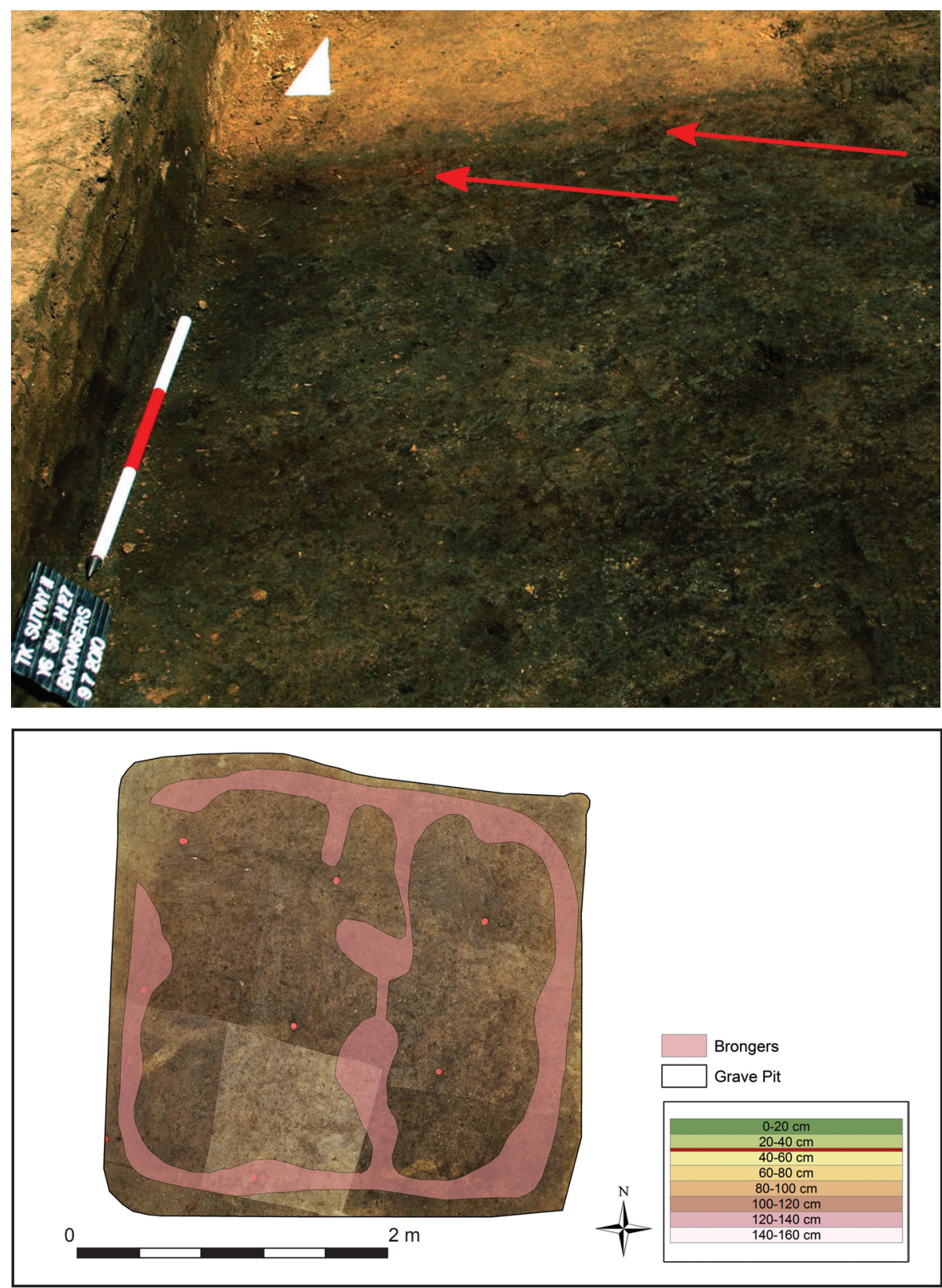

Figure 10. An example of a manifestation of Brongers method at the edge of the fill of the grave $\mathrm{H} 27$ (the red colour level increased in graphic editor).

Figure 11. Result interpretation of field visualization of wooden structure remnants with Brongers method at the recording level $40 \mathrm{~cm}$. 
Figure 12. Result interpretation of field visualization of wooden structure remnants with Brongers method at the recording level $110 \mathrm{~cm}$.
Figure 13. An example of the appearance of Brongers method at the base of one of the cups in grave $\mathrm{H} 27$ (red colour level increased in graphic editor)
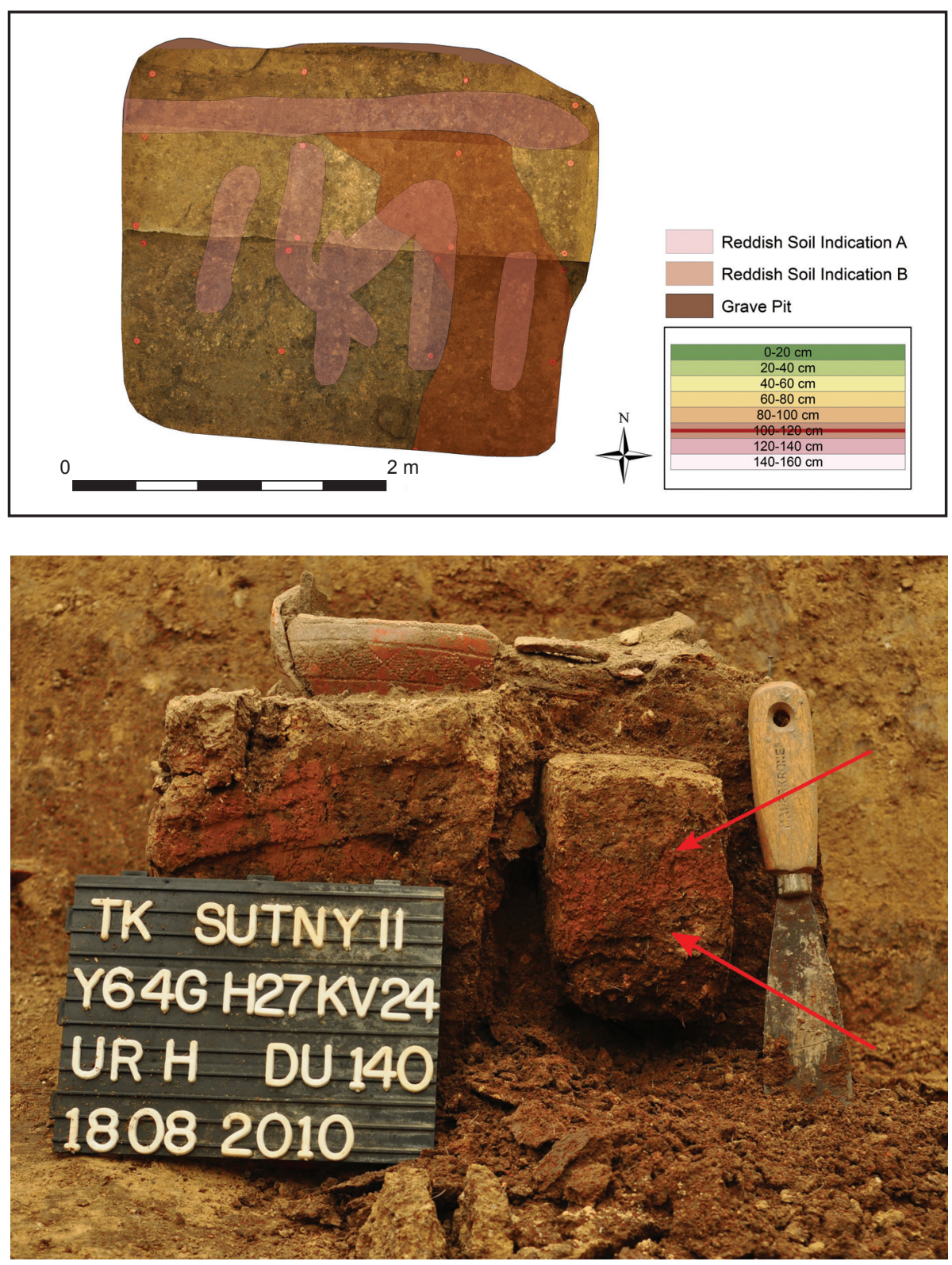

was completed simultaneously and used later as a baseline for digitalization.

\section{2 .2 Recording level $110 \mathrm{~cm}$}

Obvious southnorth dark belts were noted in the fill at this level. The width of these belts could correspond to laid wooden boards or lumber. After the application of Brongers method certain features visible to the naked eye were more clearly identifiable, and certain markings, which were not obvious earlier, appeared in part of the grave pit (Figure 12).

\subsubsection{Recording level $140 \mathrm{~cm}$}

An unclear organic structure has been detected in the eastern part of the chamber just above the floor level. The subsoil had already been reached, however, in the majority of the grave area at this level. The organic structure became more obvious after the application of Brongers method. It appeared to be a two-part construction (Figure 13). This situation looks quite similar to the interior of the grave from nearby archaeological site at Hodonice (D. Humpola's report from work meeting: Questions of Neolithic and Eneolithic periods, Mikulov, Sept. 20, 2011.), excavated the same year. Similar reddish belts were also noted on vertical profiles directly under the cups (Figure 14).

\section{Discussion}

The usefulness of phosphate analysis during grave excavations has already been demonstrated and should properly constitute a regular part of all burial investigations. The J. A. Brongers method provides new evidence of previously undetected wooden structures within the chamber at Těšetice-Kyjovice "Sutny". 


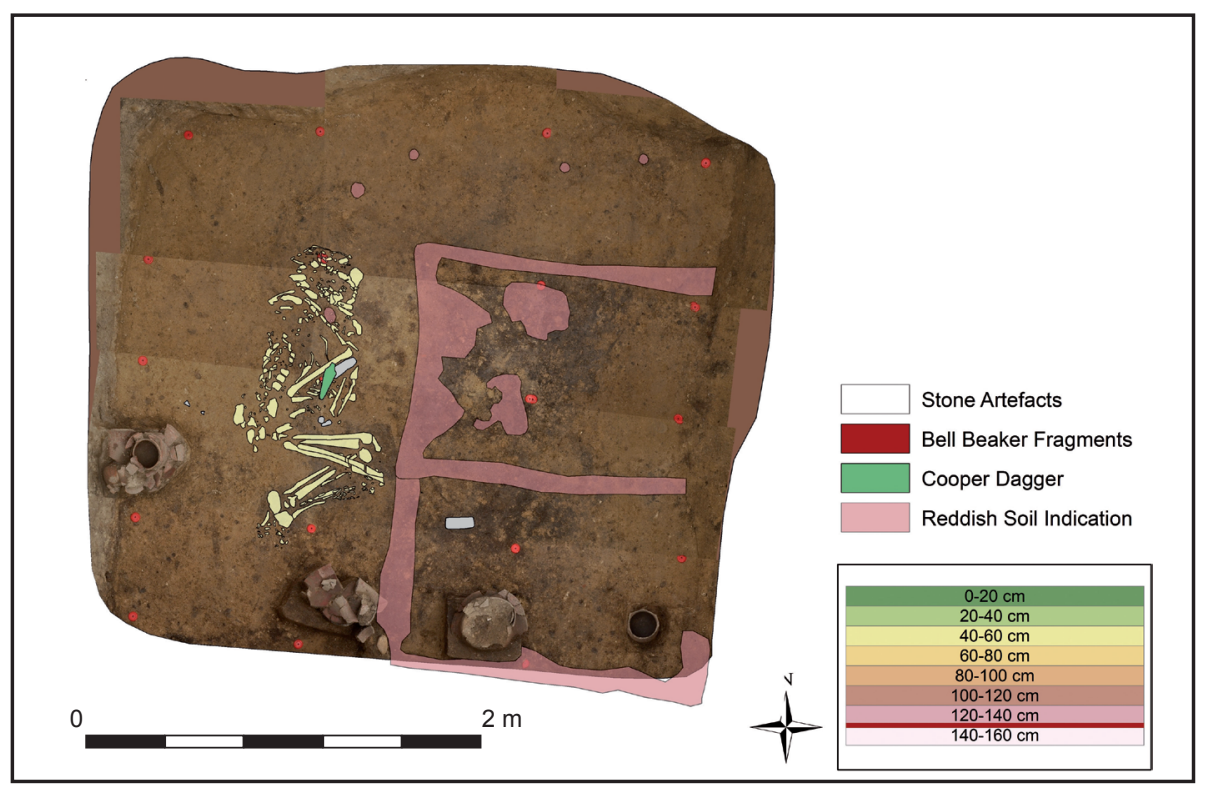

Figure 14. Result interpretation of field visualization of wooden structure remnants with Brongers method at the recording level $140 \mathrm{~cm}$.

The analysis at the $130 \mathrm{~cm}$ level indicates the highest phosphate concentration in the area of the skeleton with a slight shift to the east. This could be explained by gravity pulling decaying remains along the slightly sloped pit base. The interpolation results of the phosphate values under the skeleton (at the $140 \mathrm{~cm}$ level) reveal phosphate concentration

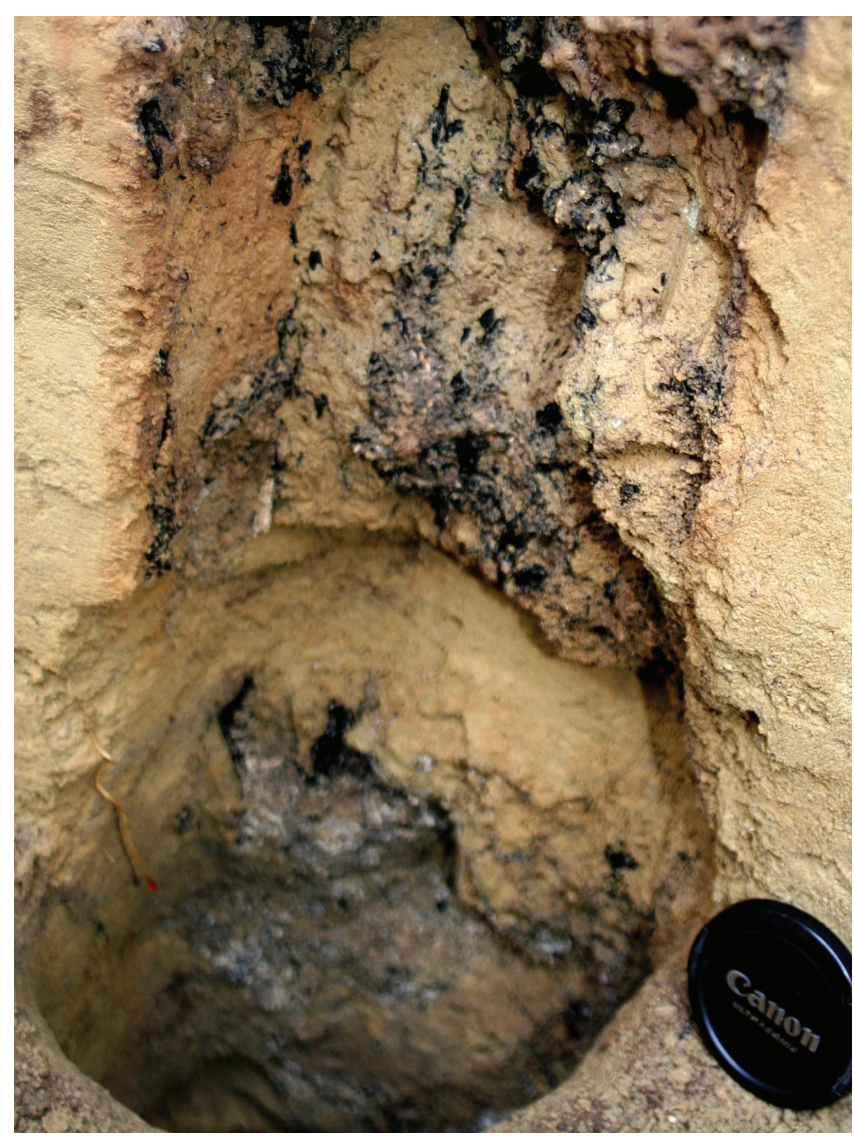

Figure 15. An example of manifestation of decayed wood at the edges of a post pit after the application of Brongers method, site: Kyjov, district of Hodonín. under the skeleton at the abdominal cavity, pelvis and thighs, which can be clearly interpreted in light of published studies (e.g. Ernée, Majer 2009).

A direct comparison of the phosphate soil analysis by different authors and from different sites is difficult due to the dissimilarity of the site characterization and different methods of analyses. It has, however, been repeatedly observed that high phosphate concentrations in the area of the skeleton is a consequence of soft tissue decomposition (Pelikán 1954; Van den Voort 1982; Prokeš 2007).

Taphonomical observation presents important supporting evidence. In this case, the skeleton in the articulated position without apparent abnormality in anatomically correct position (Petřík et al. 2012, 50) is interpreted as evidence of soft tissue decomposition in the area of the burial (Duday, Guillon 2006; Duday 2009).

The attempt to identify phosphates while in the field, between levels $130 \mathrm{~cm}$ and $140 \mathrm{~cm}$, found a phosphate anomaly in the skeleton area (including the right shift as in the total phosphates at the $130 \mathrm{~cm}$ level). The phosphate anomaly detected, however, in the southeast corner at the $140 \mathrm{~cm}$ level was missing.

Spots in the western and the northeast part of the grave were not detected by phosphate analysis. The differences could originate from the fact that during the application of reactive agents using Eidt method (1977) there was not a complete release of soil phosphates.

The usefulness of J.A. Brongers method of organic structure identification was demonstrated by the authors on several loess sites in the Czech Republic (Figure 15). This method allowed us to identify decayed wooden features at several levels of the grave chamber. The outline of a wooden casing in the grave pit, and wooden dividers or beams through the centre of the grave chamber, was detected at the $40 \mathrm{~cm}$ level. Prior to the use of Brongers method, researchers did not except any obvious signs of the presence of wooden features in the centre or on the surface of the grave pit. The 
Figure 16. Result interpretation of field visualization of wooden structure remnants with Brongers method and soil phosphates values interpolated by the Natural Neighbour method.

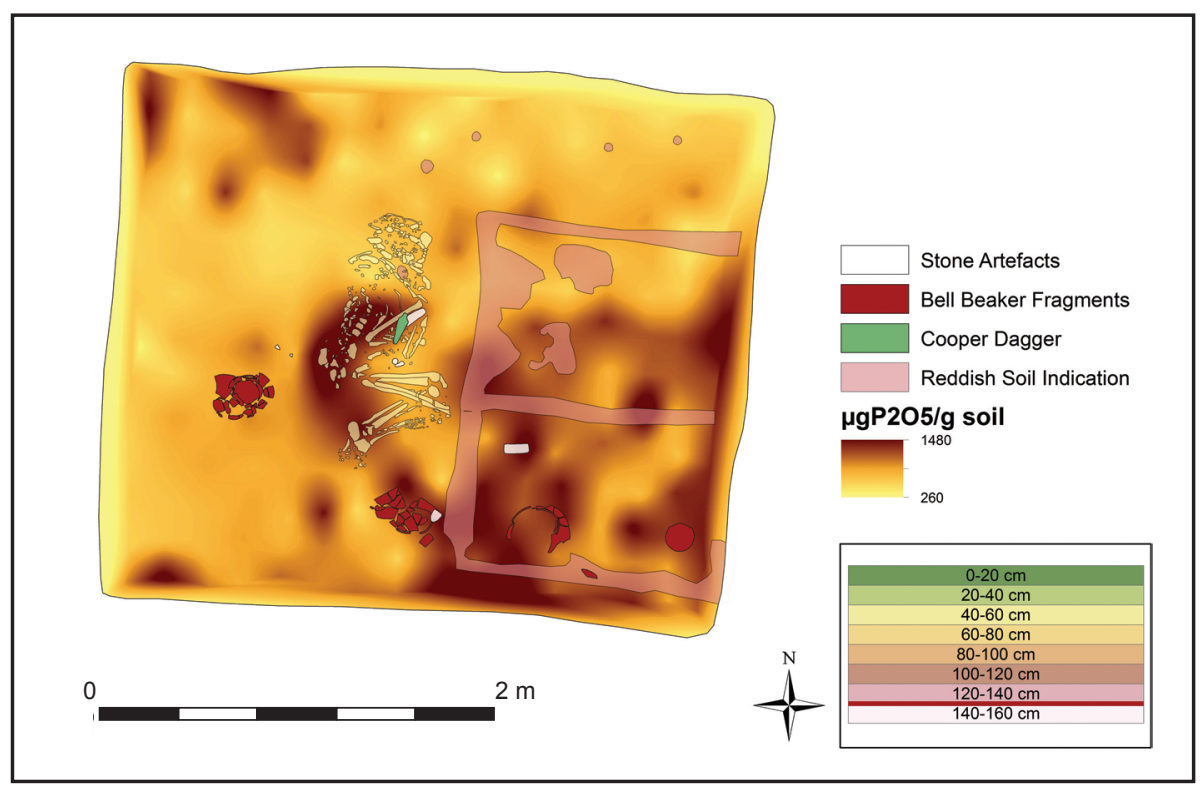

clear delineation of these wooden features using this method was surprising and supports the argument that it provides objective in situ evaluations. The identification of wooden features at the 110 and $140 \mathrm{~cm}$ levels corresponded with the naked eye observations of colour differences, but also made more a detailed and broader interpretation possible. Evidence of wooden features at the bottom of the grave pit at the $140 \mathrm{~cm}$ level is analogous with the simultaneously excavated site at Hodonice. Further applications of this method in similar archaeological contexts are necessary in order to better understand the method. The development of a recording method for the outlines depicted as a result of the application of Brongers method is still needed. It is difficult to capture the complex image using photogrammetry.

\section{Conclusions}

Significant concentrations of phosphates were detected within the grave complex at the burial level and directly underneath. It is obvious from the context that the body was deposited into the grave chamber before soft tissue decomposition occurred. The second and lower concentration of phosphate is related to organic additions placed into the grave chamber. J.A. Brongers method for detecting decomposed wood allowed for the identification of certain pit features at the $40 \mathrm{~cm}$ level, and provided a more complex picture of other features previously outlined in the pit at the $110 \mathrm{~cm}$ and $140 \mathrm{~cm}$ levels. Recorded features are interpreted as the remains of a wooden structure along the chamber wall, a divider wall or top cover at the $40 \mathrm{~cm}$ level, slabs covering the chamber at the $110 \mathrm{~cm}$ level, and parts of a wooden structure at the $140 \mathrm{~cm}$ floor level. This east side bottom structure could have been used as deposit of funerary goods. This theory is supported by a feature that corresponds with the phosphate anomaly in the southeast corner of the grave chamber (Figure 16). The combination of the data obtained throughout the grave context can be utilized within GIS systems to develop a reconstruction of the grave chamber structure and the burial process.

\section{Acknowledgements}

The realization of the field research and its further development was covered by the research project MSM 0021622427, of grants GAČR GD 404/09/H020 and GAČR 404/09/1825. Partial expenses were covered from the operational programme - Education for the ability to compete - Education in modern methods of archaeological practice (reg. no. CZ.1.07/2. 3.00/09.0187). We would like to thank all the colleagues from our excavation team.

\section{References}

BARKER, H., HUGHES, M. J., ODDY, W. A., WERNER, A. E. 1975: Report on phosphate analyses carried out in connection with the cenotaph problem. In: Bruce-Mitford, R. C. S. (Ed.): The Sutton Hoo Ship-Burial 1, British Museum, London, 550-572.

BRONGERS, J. A. 1962-63: A chemical method for staining places and profiles in an archaeological excavation, Berichten van de Rijksdienst voor Oudheidkundig Bodemonderzoek 12-13, 590.

CAVANAGH, W. G., HIRST, S., LITTON, C. D. 1988: Soil phosphate, site boundaries and change point analysis, Journal of Field Archaeology 15, 67-83.

CROWTHER, J. 2002: The experimental earthwork at Wareham, Dorset after 33 years: retention and leaching of phosphate released in the decomposition of buried bone, Journal of Archaeological Science 29, 405-411.

EIDT, R. C. 1977: Detection and examination of anthrosols by phosphate analysis, Science 197, 1327-1333.

DUDAY, H. 2009: The Archaeology of the Dead. Lectures in Archaeothanatology. Oxford, Oxbow Books.

DUDAY, H., GUILLON, M. 2006: Understanding the circumstances of decomposition when the body is skeletonised. In: Schmitt, A., Cunha, E., 
Pinheiro J. (Eds.): Forensic Anthropology and Medicine: Complementary Sciences from Recovery to Cause of Death. Humana Press, Totowa, $117-157$.

DUMA, G. 1972: Phosphate content of ancient pots as indication of use, Antiquity 13, 1, 126-129.

ERNÉE, M., MAJER, A. 2009: Uniformita, či rozmanitost pohřebního ritu? Interpretace výsledků fosfátrové půdní analýzy na pohřebišti únětické kultury v Praze 9 - Miškovicích - Uniformität oder Vielfalt des Bestattungsritus? Interpretation der Ergebnisse der Phosphatanalyse auf dem Gräberfeld der Aunjetitzer Kultur in Prag 9-Miškovice - Uniformity or diversity of the burial ritual? Phosphate soil analysis interpretation from the burial site of Unetice Culture at the Prague 9-Miškovice site, Archeologické rozhledy 61, 493-508.

KUČA, M., ŠABATOVÁ, K., TRAMPOTA, F., KAZDOVÁ, E., PROKEŠ, L., KOLÁŘ, J., PETŘÍK, J., HLOŽEK, M., in print: Kyjovice (Znojmo), Přehled výzkumů 52, Brno.

MAJER, A. 1984: Relativní metoda fosfátové půdní analýzy - The relative method of phosphate analysis of soil, Archeologické rozhledy 36, 297-313.

NÚÑEZ, M. 1975. Phosphorus determination of the graves of Kilteri in Vantaa, Southern Finland, Suomen Museo 82, 18-25.

HOLLIDAY, V. T., GARTNER, W. G. 2007: Methods of soil P analysis in archaeology, Journal of Archaeological Science 34, 301-333.

PELIKÁN, J. B. 1954: Chemický posudek k výzkumu v Brodcích n. J v roce 1953 - Результаты химического исследования могильника в общ. Бродцы над Изерой в 1953 г. - Die Ergebnisse der chemischen Untersuchung des Gräberfeldes in Brodce n. Jiz, Památky archeologické $45,324-328$
PETŘíK, J., PROKEŠ, L., HUMPOLA, D., FAJKOŠOVÁ, Z., KUČA, M., ŠABATOVÁ, K., KAZDOVÁ, E. 2012: Pedogeochemical investigation of the Bell Beaker Culture graves from sites Hodonice and TěšeticeKyjovice, South Moravia. In Koláŕ, J., Trampota, F. (Eds.): Theoretical and Methodological Considerations in Central European Neolithic Archaeology Proceedings of the 'Theory and Method in Archaeology of the Neolithic $\left(7^{\text {th }}-3^{\text {rd }}\right.$ millennium BC) BAR S2325, Oxford, 45-64.

SIBSON, R. 1981: A brief description of natural neighbor interpolation (Chapter 2). In: Barnett, V. (Ed.): Interpreting Multivariate Data. Chichester, 21-36.

PIGGOTT, S. 1956. Excavations in Passage-graves and Ring-Cairns of the Clava Group, 1952-3, Proceedings of The Society of Antiquaries of Scotland 88, 200-207.

PROKEŠ, L. 2007: Posmrtné změny a jejich význam při interpretaci pohřebniho ritu (ke vztahu mezi archeologii a forenznimi védami). Archaeologia Mediaevalia Moraviana et Silesiana, Suppl 1. Brno.

STOYE, K. 1950. Die Anwendung der Phosphatmethode auf einem mittelalterlichen Friedhof, Jahresschrift für Mitteldeutsche Vorgeschichte $34,180-184$.

TUREK, J., MAJER, A. 1999: Př́ílad aplikace fosfátové půdní analýzy na pohřebním areálu v Tišicích (okr. Mělník) - An Application of the Phosphate Analysis on the Prehistoric burial find from Tišice (Mělník District), Archeologie ve střednich Čechách 3, 205-212.

ROTTLÄNDER, R. 1970: Chemische Bodenuntersuchung für den Archäologen, Informationsblätter zu Nachbarwissenschafen der Ur und Frühgeschichte 1 (Chemie 1), 1-20.

VAN DEN VOORT, W. J. M. 1982: Phosphate determinations of a cemetery in the Wageningen Eng, the Netherlands, Berichten van de Rijksdienst voor Oudheidkundig Bodemonderzoek 32, 139-145. 